\title{
PENGEMBANGAN MODUL BERWAWASAN LINGKUNGAN DALAM RANGKA MENINGKATKAN PENGETAHUAN DAN MORAL LINGKUNGAN SISWA SD DI DAERAH INDUSTRI, KOTA, PANTAI DAN DESA
}

\author{
Bambang Gonggo Murcitro
}

\begin{abstract}
This research is directed to create enviromental friendly moduls that can be used for improving knowledge and moral of elememtary student enviromentals in industrial areas, cities, beach and farming areas. The research was condusted on 150 elementary students of the sixth grade selected with cluster random sampling.

The research resulth showed that: 1) The moduls could be em ployed to increase the knowledge of elementary students about enviroments in industrial areas, beach, cities and farming areas. Through the testing of the hypothesis on the student knowledge data using Anacova test, it was obtained the calculated F as big as 1.98 that less than the table F value 2.68. 2) Enviromental friendly moduls can be utilized to increase the moral of elementary student concerning environments industrial areas, beach, cities and forming areas. Though the hypothesis testing uses Anacova to the data of student moral about enviromental, it was obtaind that a the calculated F value as great as 0.31 that means lesses than the table F value of 2. 68 .
\end{abstract}

Kata kunci: modul, berwawasan lingkungan, pengetahuan moral dan lingkungan

\section{PENDAHULUAN}

\section{Latar Belakang}

Pembangunan adalah upaya sadar yang dilakukan oleh pemerintah atau masyarakat secara kelompok maupun pribadi yang dilakukan secara terus menerus atau berkelanjutan dengan memanfaatkan sumber daya alam dan manusia sebagai potensi pokoknya yang bertujuan meningkatkan kualitas hidup melalui perubahan tatanan kehidupan yang meliputi aspek sosial, politik, ekonomi, dan budaya secara keseluruhan. Bila dilihat dari skalanya maka kegiatan pembangunan dapat berskala besar atau kecil, skala luas atau tidaknya pembangunan serta skala lama atau tidaknya pembangunan itu dijalankan. Semakin luas dan semakin kompleks kegiatan pembangunan tersebut maka akan makin besar masalah yang ditimbulkan, makin besar pula kemungkinan resiko yang harus dihadapi untuk mencapai hasil yang diharapkan.

Upaya yang dilakukan dalam pembangunan adalah terjadinya pertumbuhan dan perkembangan sosial ekonomi yang bertujuan untuk meningkatkan kesejahteraan masyarakat. Dalam upaya untuk pertumbuhan ekonomi tersebut terkadang alam dieksploitasi diluar daya dukungnya sehingga menimbulkan dampak yang tidak terduga terhadap lingkungan hidup maupun terhadap sosial.
Terjadinya pencemaran dan degradasi sumber daya alam merupakan salah satu contoh dampak negatif kegiatan pembangunan yang lebih mementingkan pertumbuhan ekonomi daripada daya dukung lingkungan. Terjadinya kesenjangan sosial juga merupakan satu akibat pembangunan yang tidak merrata dan tidak mengacu pada pertimbangan wilayah. Kesenjangan tersebut merupakan salah satu faktor utama meluasnya kasus kemiskinan dimanamana.

Akibat eksploitasi alam yang tidak terkendali pada berbagai sektor secara terus menerus bukan hanya pada tingkat lokal, namun juga tingkat daerah, pulau atau wilayah negara, hal ini menyebabkan masalah lingkungan terus meluas secara transnasional yakni menjadi masalah regional dan global. Masalah lingkungan saat ini telah menjadi masalah internasional yang sangat mendesak untuk diselesaikan melalui kerjasama internasional.

Sebagai generasi penerus siswa perlu dididik agar dapat memahami konsep perkembangan kependudukan dan lingkungan. Oleh sebab itu siswa perlu mendapatkan pendidikan lingkungan sejak awal untuk menanamkan dan membentuk kesadaran lingkungannya.

Pendidikan diharapkan merupakan wadah yang tepat untuk menanamkan persepsi dan kesadaran siswa tentang lingkungan, faktor-faktor 
yang menyebabkan turunnya kualitas lingkungan dan peran serta manfaat lingkungan bagi kehidupan di Bumi saat ini maupun generasi yang akan datang.

Untuk mewujudkan tujuan pembelajaran tersebut, perlu dibuat strategi dan bahan ajar yang sesuai dengan pola berpikir siswa. Agar lebih bermakna maka bahan ajar tersebut harus disukai siswa, siswa dapat bermain sekaligus belajar, selain itu bahan pengajaran tersebut harus memberikan banyak informasi tentang lingkungan dan faktorfaktor yang mempengaruhinya dan yang terpenting melalui bahan ajar tersebut dapat ditanamkan etika dan moral lingkungan kepada siswa. Dengan memiliki etika dan moral lingkungan maka diharapkan tingkah-laku siswa pada saat berinteraksi dengan lingkungan dilandasi oleh etika dan moralnya tentang lingkungan. Bentuk pengajaran dan bahan pengajaran seperti inilah yang saat ini belum banyak diterapkan kepada siswa.

Atas dasar uraian di atas, maka penelitian ini akan membahas masalah tentang pengembangan modul berwawasan lingkungan yang dapat digunakan untuk meningkatkan pengetahuan dan moral lingkungan siswa kelas V SD dengan pertimbangan bahwa siswa kelas $\mathrm{V}$ telah mendapatkan pengetahuan awal dari berbagai materi ajar yang menjadi dasar pembelajaran lingkungan hidup yang merupakan pengetahuan yang interdisipliner. Alasan lain adalah bahwa siswa kelas V SD dianggap telah berusia cukup untuk menerima materi pembelajaran sehingga mereka dapat meningkatkan pengetahuan, perubahan sikap dan penerapan pengetahuan. Selain itu anak usia SD sedang dalam taraf perkembangan moral sehingga pada usia tersebut adalah waktu yang tepat untuk membentuk moral lingkungannya.

\section{Perumusan Masalah}

Berdasarkan latar belakang masalah, identifikasi masalah dan pembatasan masalah yang memfokuskan pada faktor-faktor yang menentukan terhadap pengetahuan dan moral lingkungan siswa SD maka masalah yang akan diteliti pada penelitian ini dirumuskan sebagai berikut:

Apakah modul berwawasan lingkungan yang disusun dapat digunakan untuk meningkatkan pengetahuan lingkungan siswa SD di daerah industri, kota, pantai dan pedesaan? (2). Apakah modul berwawasan lingkungan yang disusun dapat digunakan untuk meningkatkan moral lingkungan siswa SD di daerah industri, kota, pantai dan pedesaan?

\section{KAJIAN TEORITIK}

\section{Pengetahuan Lingkungan}

Manusia merupakan mahluk ciptaan Tuhan yang paling sempurna. Kesempurnaan manusia tersebut terletak pada akal budi yang dimilikinya. Dengan akal budi tersebut manusia memenuhi hasrat ingin tahunya tentang segala sesuatu yang dijumpainya di muka Bumi ini. Hasrat ingin tahu manusia ini tidak pernah terpuaskan. Manusia terus mencari dan ingin membuka tabir rahasia alam yang belum diketahuinya. Hasrat ingin tahu manusia diawali pada masalah-masalah pokok yang dijumpainya sehari-hari misalnya mengapa terjadi siang, mengapa terjadi malam, mengapa terjadi gempa bumi dan gunung meletus, mengapa terjadi gerhana dan masalah-masalah pokok lainnya. Untuk menjawab masalah-masalah tersebut manusia mencoba mencari jawabannya yang sangat sederhana dan kadang jauh dari realita. Sejak saat itulah manusia menciptakan pengetahuan. Setelah mengetahui masalah-masalak pokok yang dijumpainya dalam kehidupan sehari-hari manusia mengalihkan hasrat ingin tahu tersebut kepada masalah-masalah yang lebih kompleks misalnya masalah atom dan elektron. Oleh sebab itu pengetahuan manusia juga semakin lama menjadi kompleks seperti pengetahuan yang terdapat pada konsep-konsep ilmu pengetahuan modern. Ditinjau dari sumbernya, pengetahuan dalam pendidikan dapat dibedakan menjadi lima jenis pengetahuan yaitu: (1) pengalaman, (2) otoritas, (3) metode deduktif, (4) metode induktif dan (5) metode ilmiah (Rukiah, 1986: 9)

Pengalaman merupakan hasil kerja panca indera terhadap objek yang dijumpai manusia dalam kehidupan sehari-hari. Dengan indera matanya manusia dapat melihat bentuk benda-benda, besar kecilnya benda, warna benda, gerakan benda dan lainlain. Otoritas merupakan sumber pengetahuan yang berasal dari pernyataan orang yang dianggap tahu atau lebih berpengalaman dalam bidang tertentu. Metode deduktif sebagai sumber pengetahuan didefinisikan sebagai suatu proses berpikir dari teoriteori yang bersifat umum untuk menarik masalahmasalah yang bersifat khusus dengan menggunakan logika. Proses berpikir semacam ini banyak digunakan dalam penelitian pendidikan. Untuk mendapatkan pengetahuan secara deduktif digunakan sejumlah pernyataan yang sering disebut silogisme.

Sebagai sumber pengetahuan, metode induktif sering didefinisikan sebagai cara berpikir

Perspektif Ilmu Pendidikan - Vol. 13 Th. VII April 2006 
dengan cara mengumpulkan fakta-fakta yang bersifat khusus untuk diambil kesimpulan yang bersifat umum. Penelitian dalam bidang teknik dan kedokteran sering menggunakan pola berpikir secara induktif.

Sebagai sumber pengetahuan metode ilmiah melakukan proses pengujian yang dikenal dengan langkah-langkah lmiah. Saat ini umumnya dikenal lima langkah dalam metode ilmiah yaitu: (1) menemukan dan merumuskan masalah, (2) penyusunan teori, (3) merumuskan hipotesis, (4) menguji hipotesis melalui eksperimen dan (5) menarik kesimpulan (Jujun, 1984: 47).

Istilah pengetahuan digunakan sebagai terjemahan dari kata knowledge. Beberapa materi pelajaran yang termasuk dalam ranah pengetahuan adalah pengetahuan faktorial disamping pengetahuan hafalan atau materi pelajaran yang perlu diingat seperti rumus, batasan, definisi, istilah, pasal dalam undang-undang, nama-nama tokoh, nama kota dan materi-materi lainnya yang bersifat hafalan (Nana, 1990: 23.)

Dalam taksonomi tujuan pendidikan, pengetahuan termasuk ranah kognitif bersama dengan pemahaman, aplikasi, analisis, sintesis dan evaluasi. (Norman, 1985: 514). Berbeda dengan tujuan kognitif lainnya, tujuan pendidikan pengetahuan lebih mementingkan aspek mengingat materi pelajaran. Oleh sebab itu materi pelajaran yang disampaikan juga bersifat sederhana, misalnya materi-materi yang bersifat pengantar atau materi kemampuan awal adalah bentuk-bentuk materi yang sesuai dengan tujuan pendidikan ranah pengetahuan.

Dalam Taksonomi Bloom, pengetahuan dapat diklasifikasikan menjadi: (1) pengetahuan akan halhal khusus yang meliputi pengetahuan tentang istilah dan kejadian-kejadian khusus, (2) pengetahuan tentang cara dan alat untuk berhubungan dengan halhal khusus yang terdiri dari pengetahuan konvensi, pengetahuan tentang arah dan urutan, pengetahuan tentang kriteria dan pengetahuan metodologis, (3) pengetahuan akan hal-hal umum dan abstrak dalam bidang tertentu yang terdiri dari pengetahuan akan prinsip dan generalisasi serta pengetahuan teori dan struktur. (Krathewahl, 1964: 186). Davies (1991: 105) merumuskan kata kerja yang sesuai untuk tujuan instruksional khusus dalam mengukur pengetahuan adalah: mendefinisikan, menyebutkan, mendaftar, menamakan, menuliskan, mengenal, mengemukakan, melabelkan, menggarisbawahi, memilih, mereproduksi dan mengukur.
Secara lebih lengkap Soerjani (1987:3) menyatakan bahwa yang dimaksud dengan lingkungan hidup adalah sistem yang merupakan kesatuan ruang dengan semua benda, daya, keadaan dan mahluk hidup termasuk manusia dan perilakunya yang menentukan perikehidupan serta kesejahteraan manusia dan mahluk hidup lainnya. Yang dimaksud dengan ruang adalah area atau tempat dimana mahluk hidup tersebut berada dan melakukan aktifitas hidupnya. Dengan demikian dimanapun terdapat komponen lingkungan hidup, maka akan terdapat ruang yang mengitarinya. Oleh sebab itu antara ruang dan komponen lingkungan merupakan satu kesatuan.

Sementara itu Valentinus Darsono (1995:17) membedakan lingkungan hidup menjadi 3 bagian yaitu: (1) lingkungan fisik, yaitu segala sesuatu yang ada disekitar kita yang berwujud benda mati seperti gedung, jembatan, candi dan lain-lain, (2) lingkungan biologi, yaitu segala sesuatu yang berada disekitar kita yang berwujud benda hidup seperti manusia, hewan tumbuhan dan jasad renik, (3) lingkungan sosial, yaitu manusia-manusia lain yang berada disekitarnya.

Bila definisi tentang lingkungan hidup tersebut dihubungkan dengan pengertian tentang pengetahuan, maka yang dimaksud dengan pengetahuan tentang lingkungan adalah seperangkat materi pelajaran yang diperoleh siswa sesudah mendapat pelajaran tentang lingkungan. Pengetahuan lingkungan ini dapat diketahui dari skor hasil belajarnya.

\section{Moral Lingkungan}

Moral yang berarti adat, istiadat, kebiasaan, cara tingkah, kelakuan. Moral berasal dari kata latin moris yang artinya adat, istiadat, kebiasaan, kelakuan, tabiat, watak, akhlak, cara hidup. Jadi moral adalah aturan atau cara hidup yang bersifat normatif yang sudah ikut serta dalam kehidupan manusia seiring dengan umur yang dijalani manusia. (Nuraini, 2002: 3.)

Abudin Nata (2000) menyatakan bahwa moral adalah kelakuan yang sesuai dengan ukuran-ukuran (nilai-nilai) masyarakat yang timbul dari hati dan bukan paksaan dari luar yang disertai pula oleh rasa tangung jawab atas tindakan tersebut. Tindakan tersebut harus mendahulukan kepentingan umum daripada kepentingan atau keinginan pribadi.

Hurlock (1994: 225) menyatakan bahwa kode moral berkembang dari konsep-konsep moral yang umum. Pada akhir masa kanak-kanak kode moral 
tersebut sangat dipengaruhi oleh standar moral dari kelompoknya. Kohlberg, (1977) dalam Budiningsih (2001) menyatakan tahapan-tahapan perkembangan moral sebagai berikut: pertama; tingkat prakonvensional, yang dapat dibagi 2 tahap yaitu (a) tahap orientasi hukum dan kepatuhan dan (b) tahap orientasi instrumentalis, kedua; tingkat konvensional, yang terdiri dari 2 tahap yaitu, (c) orientasi kerukunan atau orientasi good boy-nice girl dan (d) orientasi keterlibatan masyarakat, ketiga; tingkat pasca-konvensional atau tingkat otonom, yang terdiri dari 2 tingkat yaitu (e) orientasi kontak sosial dan (f) orientasi prinsip etis universal. Rest (1984) dalam Cheppy (1995: 210) menyatakan bahwa moralitas mencakup makna yang sangat luas diantaranya: (1) tingkah laku membantu orang lain, (2) tingkah laku yang sesuai dengan norma-norma sosial, (3) internalisasi norma-norma sosial, (4) timbulnya empati atau rasa salah atau bahkan keduanya, (5) penalaran tentang keadilan dan (6) memperhatikan kepentingan orang lain.

Berkaitan dengan pendidikan moral, pertanyaan berikutnya yang timbul adalah bagaimanakah strategi pendidikan moral dapat dilakukan. Menurut Cheppy (1988: 28) terdapat enam model pendidikan moral yaitu: (1) model pengembangan rasional, (2) model konsiderasi, (3) model klarifikasi nilai, (4) model analisis nilai, (5) model perkembangan moral kognitif dan (6) model aksi sosial.Dalam proses pendidikan moral, akan disampaikan nilai-nilai budaya yang mengandung nilai-nilai moral atau norma-norma moral yang sesuai dengan budaya masyarakat atau bangsa. Pendidikan moral tersebut dapat dilakukan oleh orang tua, pendidik, pemuka masyarakat, tokoh agama pada peserta didik sepanjang hidup. Melalui pendidikan moral yang diawali dari keluarga, lingkungan sekolah dan masyarakat akan menyebabkan terjadinya perkembangan moral secara berlanjut dari masa anakanak hingga dewasa, dan dari masa dewasa berlanjut sampai tua. Dengan demikian dapat dikatakan bahwa proses pendidikan moral merupakan proses pembudayaan dan proses transformasi nilai-nilai budaya.

\section{Pengajaran Modul}

Diantara berbagai bentuk pengajaran individual, maka pengajaran modul merupakan salah satu alternatif yang dapat digunakan karena mampu mengatasi kelemahan sistem pengajaran klasikal.
Bahkan para pendidik yang sangat meyakini keampuhan pengajaran modul meramalkan bahwa dimasa yang akan datang, seluruh kurikulum untuk disipliner maupun interdisipliner akan disajikan dalam bentuk modul yang dapat memberikan program yang sesuai dengan kebutuhan setiap siswa. (Nasution, 1992:. 205)

Modul sebagai model pengajaran individual diharapkan mampu mengubah keadaan tersebut menjadi situasi belajar mengajar yang lebih mengaktifkan siswa untuk membaca dan belajar memecahkan masalah sendiri di bawah bimbingan seorang guru yang selalu siap menolong siswa yang mengalami kesulitan.

Selain itu modul ternyata dapat membantu 4 masalah pokok dalam dunia pendidikan yang sedang terjadi saat ini yaitu: (1) masalah yang berhubungan dengan pemerataan pendidikan, (2) masalah yang berhubungan dengan relevansi pendidikan, (3) masalah yang berkaitan dengan masalah pendidikan dan (4) masalah yang berhubungan dengan efisiensi pendidikan. (Suryosubroto, 1984: 12.)

Pengertian modul menurut Engkoswara (1988:98) adalah sebagai berikut:

Modul adalah suatu unit program mengajar terkecil yang secara terperinci mengariskan: (1) Tujuan instruksional umum yang akan ditunjang pencapainya kemudian, (2) Topiktopik yang akan dijadikan pangkal proses belajar mengajar, (3) Tujuan-tujuan instruksional khusus yang akan dicapai oleh siswa, (4) Pokok-pokok materi yang akan dipelajari dan diajarkan, (5) kedudukan dan fungsi satuan (modul) dalam kesatuan program yang lebih luas, (6) Peran guru dalam proses mengajar, (7) Alat-alat dan sumber yang akan dicapai, (8) kegiatan belajar yang baru dilakukan dan dihayati oleh murid secara berurutan, (9) lembaran-lembaran kerja yang harus diisi oleh siswa dan (10) Program evaluasi yang akan dilaksanakan selama berjalannya proses belajar.

Perbedaan antara sistem pengajaran modul dengan sistem pengajaran klasikal dapat dlihat pada tabel di bawah ini: 
Tabel 1. Perbedaan Sistem Pengajaran Modul dengan Klasikal

\begin{tabular}{|c|c|c|c|}
\hline No & Kriteria Perbedaan & Pengajaran Klasikal & Pengajaran Modul \\
\hline 1 & Tujuan & $\begin{array}{l}\text { Tujuan tidak dirumuskan } \\
\text { secara spesifik }\end{array}$ & $\begin{array}{lr}\text { Tujuan dirumuskan secara } \\
\text { spesifik dalam bentuk } \\
\text { kelakuan siswa }\end{array}$ \\
\hline 2 & Bahan Pelajaran & $\begin{array}{l}\text { Disajikan kepada kelas } \\
\text { sebagai keseluruhan }\end{array}$ & Disajikan secara individual. \\
\hline 3 & $\begin{array}{l}\text { Kegiatan } \\
\text { Instruksional }\end{array}$ & $\begin{array}{l}\text { Sebagian besar berbentuk } \\
\text { ceramah }\end{array}$ & $\begin{array}{l}\text { Menggunakan berbagai } \\
\text { kegiatan }\end{array}$ \\
\hline 4 & Pengalaman belajar & $\begin{array}{l}\text { Berorientasi pada kegiatan } \\
\text { guru }\end{array}$ & $\begin{array}{l}\text { Berorientasi pada kegiatan } \\
\text { murid }\end{array}$ \\
\hline 5 & Partisipasi & $\begin{array}{l}\text { Pada umumnya siswa } \\
\text { bersifat pasif }\end{array}$ & Siswa aktif melakukan kegiatan \\
\hline 6 & Kecepatan belajar & $\begin{array}{l}\text { Semua siswa harus belajar } \\
\text { menurut kecepatan yang } \\
\text { sama }\end{array}$ & $\begin{array}{l}\text { Siswa belajar sesuai dengan } \\
\text { kecepatan masing-masing }\end{array}$ \\
\hline 7 & $\begin{array}{l}\text { Keberhasilan } \\
\text { belajar }\end{array}$ & Dinilai oleh guru & $\begin{array}{l}\text { Dinilai berdasarkan hasil } \\
\text { belajar siswa. }\end{array}$ \\
\hline 8 & Peran guru & $\begin{array}{l}\text { Berfungsi sebagai pemberi } \\
\text { informasi }\end{array}$ & Memegang berbagai peran \\
\hline
\end{tabular}

Sumber: Nasution (1992: 209)

Dari uraian diatas maka sebuah modul yang disusun dengan baik dan sistematis akan dapat memberikan keuntungan bagi siswa diantaranya: (1) memberikan umpan balik yang banyak dan cepat, (2) penguasaan tuntas materi pelajaran karena penilaian modul tidak menggunakan kurva normal, tetapi semua siswa dipacu untuk mencapai hasil yang maksimal, (3) modul mempunyai tujuan jelas, sehingga usaha siswa menjadi terarah untuk mencapainya dengan segera, (4) dapat disesuaikan dengan perbedaan siswa yang memungkinkan siswa dapat menyelesaikan materi sesuai dengan kemampuannya, (5) memungkinkan dijalinnya kerja sama antara siswa, (6) memungkinkan dilakukan pengajaran remedial yaitu memberi kesempatan siswa untuk memperbaiki kelemahan, kesalahan atau kekurangannya berdasarkan evaluasi yang diberikan.

Sementara itu bagi guru sistem pengajaran modul juga memberikan berbagai keuntungan: (1) membebaskan guru dari rutinitas karena seluruh materi pelajaran dan alat evaluasi telah tersedia dalam modul, (2) mencegah kemubaziran, karena modul telah disusun secara sistematis dan memiliki validitas yang tinggi, maka modul tersebut dapat digunakan pada berbagai sekolah atau tingkatan pendidikan, oleh sebab itu tak perlu lagi disusun modul yang sejenis oleh pihak-pihak terkait, (3) Sistem pengajaran modul memberikan kesempatan guru untuk memberikan bantuan individual bagi siswa yang memerlukan bimbingan.

\section{Lokasi Sekolah}

Hasil belajar yang dicapai oleh siswa tergantung pada banyak faktor. Masing-masing faktor tersebut memberikan pengaruh yang berbeda. Oleh sebab itu agar kegiatan belajar dapat berhasil baik, maka faktor-faktor pendukung dalam belajar perlu diaktifkan sebanyak mungkin.

Secara umum faktor-faktor yang mempengaruhi keberhasilan belajar dapat dibagi menjadi 2 macam, yaitu (1) faktor yang berasal dari dalam diri siswa yang belajar dan (2) faktor yang berasal dari luar diri siswa yang belajar atau faktor lingkungan (Arikunto, 1980: 21).

Selanjutnya dari kedua faktor tersebut yang akan menjadi perhatian dalam penelitian ini adalah faktor dari luar atau yang disebut dengan lingkungan.

Lingkungan luar yang mempengaruhi kegiatan belajar dapat dibedakan menjadi 3 macam, yaitu: (1) lingkungan alam; (2) sarana prasarana. (3) lingkungan sosial atau masyarakat. (Suryosubroto, 1988: 107).

Tonies dalam Wens (1989: 40) membedakan lingkungan sosial menjadi 2 bagian: (1) community (paguyuban) dan (2) society (patembayan). Yang termasuk community adalah kelompok atau kesatuan hidup yang bersifat tradisional. Pada kelompok ini masih terdapat ikatan kekerabatan, ikatan adat, norma maupun pandangan hidup yang diterima secara turun temurun. Yang termasuk dalam kelompok community misalnya keluarga, desa, suku, marga dan sebagainya. Sedangkan yang termasuk society merupakan kesatuan hidup bersama yang lebih bersifat modern. Pada kelompok ini juga terdapat ikatan formal dan rasional dengan aturan-aturan dan hukum yang dibuat bersama-sama dan disepakati bersama untuk mengatur kehidupan bersama dan mencapai tujuan bersama. Lingkungan sosial yang termasuk kelompok ini misalnya, kota, negara, organisasi dan lain-lain.

\section{Daerah Pedesaan}

Koentjaraningrat dalam Umar Tirtarahadja (2000: 180) membedakan 5 tipe masyarakat di Indonesia yaitu: (1) tipe masyarakat berdasarkan sistem berkebun yang sangat sederhana; (2) tipe masyarakat pedesaan berdasarkan bercocok tanam di 
ladang atau sawah dengan tanaman pokok padi yang berorientasi kepada masyarakat kota dengan peradaban kepegawaiannya; (3) tipe masayarkat pedesaan berdasarkan bercocok tanam di ladang atau sawah dengan tanaman pokok padi. Orientasinya adalah masyarakat kota yang mewujudkan peradaban bekas kerajaan, perdagangan dengan pengaruh Islam, bercampur dengan peradaban kepegawaian; (4) tipe masyarakat pedesaan berdasarkan bercocok tanam di ladang atau sawah dengan tanaman pokok padi. Tipe masyarakat ini mengalami semua gelombang pengaruh kebudayaan asing. Arah orientasinya adalah masyarakat kota yang mewujudkan peradaban kepegawaian, (5) tipe masyarakat kota yang mengembangkan sektor perdagangan dan industri.

Secara lebih khusus Sutari (1987: 138) menjelaskan tentang pengaruh iklim terhadap hasil pendidikan. Menurutnya tempat anak dibesarkan akan memberikan corak dan sikap kepada anak didik.

Adanya pengaruh yang berbeda tersebut menyebabkan terjadinya perbedaan sikap diantara mereka. Sikap anak kampung akan berbeda dengan sikap anak kota. Sikap anak gunung yang biasanya terpencil akan berbeda dengan sikap anak kampung atau anak kota. Kondisi alam dan letak geografis yang berbeda akan memberikan pengaruh terhadap sifatsifat kejiwaan anak didik.

\section{Daerah Industri}

Lingkungan industri merupakan wilayah dengan jumlah pabrik atau perusahaan yang dominan dibanding dengan keberadaan bangunan lainnya. Untuk membangun kawasan industri membutuhkan wilayah yang lebih luas. Umumnya pemerintah telah mengatur keberadaan lingkungan industri ini daerah tertentu yang jauh dari pemukiman. Tujuannya agar kondisi bising dan bahaya pencemaran tidak dirasakan oleh penduduk.

James Lee (1985: 199) wilayah yang tepat digunakan sebagai daerah industri jika dikaitkan dengan kemudahan mendapatkan bahan baku dan pemasokan energi adalah: (1) dekat dengan jaringan transportasi, (2) daerah tersebut mendukung industri dan pelayanan, (3) kemudahan mendapatkan tenaga kerja.

Wilayah industri yang seharusnya hanya digunakan untuk kegiatan perindustrian, tetapi karena keterbatasan ekonomi dan karena alasan untuk lebih dekat dengan tempat kerja, sebagian pekerja pabrik memlih bertempat tinggal di sekitar wilayah industri. Kondisi ini tentu saja menjadikan wilayah tersebut memiliki karakteristik yang berbeda dengan wilayah lainnya. Bila kondisi wilayah ini dihubungkan dengan perkembangan pengetahuan siswa, maka segala kondisi yang berada pada wilayah industri tersebut juga akan berpengaruh kepada pengetahuan dan pola pikirnya.

\section{Daerah Kota}

Dibanding dengan daerah lainnya, daerah kota memiliki karakteristik yang berbeda. Wlayah perkotaan biasanya dikaitkan dengan kepadatan, kesesakan, pencemaran dan kebisingan.

Kepadatan dapat terjadi di lingkungan pemukiman, perkantoran dan sekolah, sementara itu kesesakan dapat terjadi di jalan, tempat-tempat fasilitas umum seperti di terminal, pasar rumah sakit dan tempat-tempat lainnya. Sementara itu kebisingan dapat diakibatkan oleh deru kendaraan bermotor, alat transportasi seperti kereta dan bis kota. Selain tu kota juga ditandai dengan tingginya tingkat pencemaran yang berasal dari asap kendaraan bermotor, aktifitas penduduk, dan berbagai bentuk pemanfaatan energi lainnya. Disamping itu juga lahan terbuka sukar ditemuai karena sudah sebagian besar tertutup beton.

\section{Daerah Pantai}

Daerah pantai yang dimaksud dalam penelitian ini adalah kawasan yang meliputi lingkungan perairan pantai, termasuk lingkungan pantai itu sendiri dan lingkungan daratan pantai. Kawasan pantai berada di antara daratan dan lautan, sehingga memiliki karakteristik yang khas yang berbeda dengan wilayah lainnya.

Kondisi lingkungan pantai yang membedakan dengan lingkungan ainnya adalah faktor-faktor habitat yang disebabkan oleh tingginya hembusan angin, tingginya hembusan partikel garam, tingginya kadar garam dalam tanah, pasang surut air laut dan drainase yang tinggi.

Wilayah pantai juga kaya dengan sumber belajar karena tersedia berbagai biota pantai maupun biota darat yang tersebar sepanjang pantai. Adanya karakteristik ini akan memperkaya pola berpikir siswa yang bertempat tinggal di pinggir pantai.

Dengan demikian dapat disimpulkan bahwa lingkungan akan memberikan pengaruh yang sangat

Perspektif Ilmu Pendidikan - Vol. 13 Th. VII April 2006 
besar baik terhadap pola pikir anak maupun sifatsifat kejiwaannya. Untuk itu harus dipikirkan sebuah pola mengajar atau srategi pengajaran yang dapat mengorganisir adanya perbedaan tersebut sehingga menjadi sebuah kekuatan yang akan dapat meningkatkan pola pikir anak dan hasil belajarnya.

\section{KERANGKA BERPIKIR}

\section{Modul Berwawasan Lingkungan Dengan Lingkungan Belajar Siswa}

Sistem pengajaran klasikal di dalam kelas dengan bimbingan seorang guru yang membahas materi pelajaran tertentu memiliki beberapa kelemahan. Diantara kelemahan tersebut adalah memandang siswa memiliki kemampuan sama, menggunakan proses belajar mengajar yang sama sehingga tidak sesuai dengan kebutuhan dan kepribadian masing-masing siswa.

Modul merupakan salah satu alternatif yang dapat digunakan untuk mengatasi kelemahan dalam sistem pengajaran klasikal. Melalui pengajaran modul sistem pengajaran klasikal yang bersifat pasif diubah menjadi situasi belajar mengajar yang lebih mengaktifkan siswa untuk membaca dan belajar memecahkan masalah sendiri di bawah bimbingan seorang guru. Selain itu melalui sistem pengajaran modul maka siswa dapat belajar sendiri sesuai dengan kemampuannya, siswa dapat bekerja dan belajar tanpa harus terikat dengan tempat dan waktu. Pengajaran modul juga memungkinkan siswa belajar tanpa harus terikat oleh kondisi guru. Dengan demikian mutu pendidikan dapat meningkat tanpa harus tergantung pada kondisi guru.

Karena kelebihannya tersebut, bahkan para ahli pendidikan memprediksi bahwa dimasa yang akan datang, seluruh kurikulum yang bersifat disipliner maupun interdisipliner akan disajikan dalam bentuk modul yang dapat memberikan program yang sesuai dengan kebutuhan setiap siswa.

Modul berwawasan lingkungan merupakan suatu unit pengajaran terkecil yang memuat rangkaian kegiatan belajar yang direncanakan secara sistematis dan berisi tujuan belajar yang dirumuskan secara spesifik sehingga memungkinkan siswa belajar mandiri. Berbeda dengan modul lain pada umumnya, maka pada modul berwawasan lingkungan materinya disusun sedemikian rupa sehingga memuat pengalaman-pengalaman lingkungan yang sering dijumpai siswa dalam kehidupan sehari-hari. Keunggulan modul seperti ini bagi siswa adalah: pertama memudahkan siswa memahami materi pelajaran karena contoh-contoh yang disajikan sesuai dengan pengalamannya sehari-hari, kedua memudahkan siswa untuk mengingat materi pelajaran tersebut, ketiga memudahkan siswa mengkomunikasikan dan mendiskusikan materi pelajaran dengan siswa lainnya, keempat memudahkan siswa mengembangkan pengetahuannya, kelima memuat pengalaman pengetahuan yang merupakan bekal bagi siswa untuk mempelajari dan mengembangkan lingkungan sekitarnya.

Mencermati karakteristik sistem pengajaran modul di atas, maka dengan kelebihan modul seperti: dapat mengaktifkan siswa untuk membaca dan memecahkan masalah sendiri, siswa belajar tidak terikat oleh guru, siswa dapat belajar sesuai kemampuannya, selain itu siswa dapat belajar sesuai dengan kecepatannya masing-masing. Berdasarkan kelebihan-kelebihan tersebut maka diduga modul berawawasan lingkungan yang disusun dapat digunakan untuk meningkatkan pengetahuan siswa SD dan dapat digunakan untuk masing-masing SD dengan latar belakang lokasi sekolah yang berbeda.

\section{Modul Berwawasan Lingkungan Dengan Moral Lingkungan Siswa}

Moral merupakan aturan atau cara hidup yang bersifat normatif yang ikut serta dalam kehidupan manusia seiring dengan usia yang dijalani manusia tersebut. Dalam moral terkandung kelakuan yang sesuai dengan nilai-nilai yang dimiliki masyarakat yang disertai dengan tanggung jawab atas perbuatannya. Oleh sebab maka ajaran moral memuat tentang nilai-nilai dan norma-norma yang terdapat dalam sekelompok masyarakat tersebut.

Karena moral berisi tentang nilai dan normanorma, maka moral dapat dipelajari dan dikembangkan. Mengutip pendapat Piaget dalam Hurlock (1978) bahwa perkembangan moral terjadi dalam dua tahap yaitu tahap realisme moral dan tahap otonom. Pada tahap realisme moral seorang anak menerima peraturan, adat dan nilai tanpa penalaran atau penilaian. Mereka mengangap bahwa kewajiban anak-anak adalah mengikuti peraturan tersebut tanpa menanyakan kebenarannya. Sedangkan pada tahap moralitas otonom seorang anak mulai menalar peraturan yang dibuat oleh orang 
yang lebih dewasa dan mereka mencoba untuk memodifikasinya.

Mencermati kedua tahapan moral tersebut, maka periode yang paling tepat untuk mengembangkan moral seseorang adalah ketika pola pikirnya berada pada tahap realisme moral. Pada tahap ini akan lebih mudah untuk menerapkan adatistiadat, nilai-nilai, aturan-aturan baku yang diharapkan, karena anak kemungkinan besar akan mudah menerima dan tidak mempertanyakan apa yang harus dilakukannya. Yang termasuk tahap ini adalah ketika mereka berada pada usia belajar, tepatnya usia SD antara 6 tahun sampai dengan 12 tahun.

Salah satu lembaga yang dapat digunakan untuk mengembangkan moral adalah sekolah. Agar dapat mengembangkan moral secara optimal, maka kurikulum dan bahan pelajaran harus memuat kaidah-kaidah moral yang diharapkan.

Modul berwawasan lingkungan yang dikembangkan selain memuat konsep-konsep dasar pengetahuan lingkungan juga memuat tentang norma dan kaidah-kaidah moral lingkungan. Moral lingkungan ini disisipkan dalam modul pelajaran tentang pengetahuan lingkungan yang menjadi satu dengan alur cerita. Penggabungan antara keduanya bertujuan agar siswa mendapatkan dua keuntungan sekaligus yaitu materi pengetahuan dan materi moral lingkungan. Cara lain yang digunakan adalah dalam bentuk pesan-pesan moral yang disampaikan diakhir cerita. Melalui pesan moral tersebut maka siswa akan tahu tentang perbuatan yang boleh dan tidak boleh dilakukan kepada lingkungan, perbuatan yang akan membawa akibat secara langsung maupun tidak langsung kepada manusia maupun kepada alam itu sendiri, perbuatan-perbuatan yang melanggar etika dan susila tentang lingkungan sehingga lingkungan menjadi menurun kualitasnya. Dengan membaca materi tentang moral lingkungan yang termuat pada alur cerita dan pesan-pesan moral pada akhir cerita, maka modul berwawasan lingkungan yang disusun memiliki karakteristik yang berbeda dengan modul yang selama ini dikembangkan. Melalui pesan-pesan moral tersebut maka diduga moral siswa tentang lingkungan juga akan bertambah. Dengan demikian maka pemecahan masaah lingkungan dapat diselesaikan melalui dua pendekatan sekaligus yaitu melalui peningkatan pengetahuan dan moral siswa tentang lingkungan.

\section{Hipotesis Penelitian}

Dari uraian tentang deskripsi teori dan kerangka berpikir tersebut, maka dapat dirumuskan hipotesis penelitian sebagai berikut:

Pertama modul berwawasan lingkungan yang disusun dapat digunakan meningkatkan pengetahuan lingkungan siswa SD di daerah industri, kota, pantai dan persawahan.

Kedua modul berwawasan lingkungan yang disusun dapat digunakan meningkatkan moral lingkungan siswa SD di daerah industri, kota, pantai dan persawahan.

\section{METODOLOGI PENELITIAN}

Secara umum penelitian ini bertujuan untuk mendapatkan informasi tentang pengetahuan lingkungan dan moral siswa tentang lingkungan pada lokasi yang berbeda (kota, sawah, industri dan pantai) setelah mendapatkan modul berwawasan lingkungan.

Berdasarkan perumusan masalah yang telah dikemukakan maka secara khusus tujuan penelitian ini adalah untuk mengetahui:

Pengaruh modul berwawasan lingkungan terhadap pengetahuan siswa SD tentang lingkungan hidup di daerah industri, kota, pantai dan persawahan

Pengaruh modul berwawasan lingkungan terhadap moral siswa SD tentang lingkungan hidup di daerah industri, kota, pantai dan persawahan.

Metode penelitian yang digunakan dalam penelitian ini adalah metode eksperimen. Pada penelitian ini variabel bebas adalah modul berwawasan lingkungan $\left(X_{1}\right)$ sedangkan variabel terikatnya adalah pengetahuan lingkungan $\left(\mathrm{Y}_{1}\right)$ dan moral lingkungan $\left(\mathrm{Y}_{2}\right)$.

Pengumpulan data pengetahuan siswa dilakukan dengan instrumen tes pengetahuan lingkungan. Sedangkan pengumpulan data tentang moral siswa dilakukan dengan instrumen moral lingkungan.

Pengumpulan data dilakukan dengan cara memberi tes awal dan tes akhir. Tes awal dilakukan pada hari pertama sebelum perlakuan dimulai. Tujuan tes awal adalah (1) mengetahui pengetahuan awal siswa sebelum perlakuan, (2) memperoleh keyakinan bahwa kelompok-kelompok yang terlibat dalam eksperimen adalah homogen, (3) agar diperoleh data yang dapat dibandingkan dengan data tes akhir.

Perspektif Ilmu Pendidikan - Vol. 13 Th. VII April 2006 
Sedangkan tes akhir dilakukan pada pertemuan terakhir dari penelitian. Tujuan tes akhir adalah untuk mengetahui apakah terdapat perbedaan pengetahuan dan moral lingkungan pada kelompok perlakuan sebagai akibat adanya perlakuan yang diberikan.

Teknik analisis data yang digunakan dalam penelitian ini adalah: (1) pengujian persyaratan analisis; (2) pengujian hipotesis penelitian. Sebelum pengujian persyaratan analisis maka data penelitian dari setiap variabel dianalisis secara deskriptif untuk mendapatkan gambaran secara umum. Data yang diperoleh disajikan dalam bentuk besaran-besaran statistik deskriptif yang meliputi: rata-rata, nilai tengah, modus, simpangan baku, distribusi frekuensi dan histogram.

Syarat agar data dapat diuji dalam pengujian hipotesis adalah: (1) skor galat baku taksiran $Y$ atas $X$ berdistribusi normal. Uji normalitas menggunakan metode Liliefors; (2) variabel skor dilihat dari skor X harus bersifat homogen. Uji homogenitas menggunakan metode Bartlett.

Pengujian hipotesis untuk mengetahui pengaruh modul pada masing-masing sekolah digunakan Analisis Kovarian (Anacova).

\section{HASIL PENELITIAN}

\section{Pengujian Persyaratan Analisis}

Dari data post test pengetahuan siswa tentang lingkungan dilakukan uji normalitas dengan menggunakan Uji Lilliefors. Uji normalitas ini dilakukan untuk mengetahui apakah populasi berdistribusi normal atau tidak. Ketentuan pengujian adalah suatu populasi berdistribusi normal jika Ho diterima dan tidak berdistribusi normal jika Ho ditolak. Ketentuan tersebut secara statistik ditulis sebagai berikut:

- Ho: data berasal dari populasi berdistribusi normal

- H1: data berasal dari populasi tidak berdistribusi normal.

Langkah-langkah pengujian normalitas dengan menggunakan Uji Lilliefors diawali dengan mengurutkan data dari yang terkecil sampai yang terbesar, tahap berikutnya dihitung nilai $\mathrm{Zi}$ dengan menggunakan rumus $(x i-x / s)$ dimana xi adalah data penelitian, $x$ adalah rata-rata dan $s$ adalah simpangan baku, kemudian dihitung nilai $\mathrm{F}(\mathrm{zi})$ dengan menggunakan distribusi normal baku, kemudian dihitung proporsi $\mathrm{S}(\mathrm{zi})$ dengan menggunakan rumus banyaknya data $\mathrm{ke} \mathrm{zi} / \mathrm{n}$ dan terakhir menghitung selisih antara F(zi) - S(zi) dan ditentukan harga mutlaknya. Langkah terakhir adalah mengambil harga terbesar selisih $\mathrm{F}(\mathrm{zi})$ - $\mathrm{S}(\mathrm{zi})$ dan membandingkannya dengan nilai kritis untuk Uji Lilliefors.

Ketentuan Uji Lilliefors:

Ho diterima, jika $\mathrm{L}_{\text {hitung }}<\mathrm{L}_{\text {tabel }}$

Ho ditolak, jika $\mathrm{L}_{\text {hitung }}>\mathrm{L}_{\text {tabel }}$

Hipotesis :

- Ho : Pengetahuan siswa tentang lingkungan berdistribusi normal

- Hi : Pengetahuan siswa tentang lingkungan berdistribusi tidak normal

Rangkuman uji normalitas data post test pengetahuan siswa tentang lingkungan pada masingmasing lokasi sekolah dapat dilihat pada tabel berikut:

Tabel 2. Rangkuman uji normalitas data post test pengetahuan siswa tentang lingkungan pada masing-masing lokasi.

\begin{tabular}{|l|l|l|l|}
\hline Kelompok & $\mathrm{N}$ & $\mathrm{L}_{\text {hitung }}$ & $\mathrm{L}_{\text {thel }}$ \\
\hline Daerah Industri & 38 & 0.089 & 0.886 \\
\hline Daerah Perkotaan & 35 & 0.139 & 0.886 \\
\hline Daerah Pantai & 45 & 0.188 & 0.886 \\
\hline Daerah Persawahan & 40 & 0.109 & 0.886 \\
\hline
\end{tabular}

Karena $L_{\text {hitung }}$ pengetahuan siswa tentang lingkungan hidup pada masing-masing lokasi lebih kecil dari $\mathrm{L}_{\text {tabel }}$ maka pengetahuan siswa tentang lingkungan hidup berdistribusi normal.

Rangkuman uji normalitas data post test moral siswa tentang lingkungan pada masing-masing lokasi sekolah dapat dilihat pada tabel sebagai berikut:

Tabel 3. Rangkuman uji normalitas data post test moral siswa tentang lingkungan pada masingmasing lokasi.

\begin{tabular}{|l|l|l|l|}
\hline Kelompok & $\mathrm{n}$ & $\mathrm{L}_{\text {Hitung }}$ & $\mathrm{L}_{\text {tabel }}$ \\
\hline Daerah Industri & 38 & 0.160 & 0.886 \\
\hline Daerah Perkotaan & 35 & 0.349 & 0.886 \\
\hline Daerah Pantai & 45 & 0.184 & 0.886 \\
\hline Daerah Persawahan & 40 & 0.098 & 0.886 \\
\hline
\end{tabular}

Kriteria pengujian:

Ho diterima bila $\mathrm{L}_{\text {hitung }}<\mathrm{L}_{\text {tabel }}$

Ho ditolak bila $\mathrm{L}_{\text {hitung }}>\mathrm{L}_{\text {tabel }}$ 
Karena $\mathrm{L}_{\text {hitung }}$ moral siswa tentang lingkungan hidup pada masing-masing lokasi lebih kecil dari $\mathrm{L}_{\text {tabel' }}$ maka pengetahuan siswa tentang lingkungan hidup berdistribusi normal.

Pengujian homogenitas variansi dilakukan dengan Uji Barlett. Kriteria pengujian adalah Ho diterima jika $X^{2}$ hitung lebih kecil atau sama dengan $X^{2}$ tabel. Langkah-langkah pengujian diawali dengan membuat penyajian data. Kemudian dilanjutkan dengan menghitung $\mathrm{dk}$, variansi $\mathrm{si}^{2}$. Log $\mathrm{si}^{2}$, (dk) log $\mathrm{si}^{2}$. (dk) $\mathrm{si}^{2}$. Sebagai langkah terakhir nilai-nilai tersebut dihitung $\mathrm{X}^{2}$ dan hasilnya disebut sebagai $\mathrm{X}^{2}$ hitung.

Rangkuman uji homogenitas pengetahuan dan moral lingkungan dapat disajikan pada tabel berikut:

Tabel 4. Hasil Uji Homogenitas Variansi Pengetahuan Lingkungan.

\begin{tabular}{|l|l|l|l|l|l|}
\hline Kelompok & $\mathrm{Dk}$ & $\mathrm{Si}^{2}$ & $\mathrm{dkxSi}$ & $\mathrm{Log}^{2} \mathrm{i}^{2}$ & $\mathrm{dk}$. Log Si \\
\hline Industri & 37 & 10.819 & 400.303 & 1.034 & 38.258 \\
\hline Kota & 34 & 10.856 & 369.104 & 1.035 & 35.190 \\
\hline Pantai & 44 & 11.664 & 513.216 & 1.066 & 46.904 \\
\hline Sawah & 39 & 12.250 & 477.750 & 1.087 & 42.393 \\
\hline & 154 & 45.589 & 1760.373 & & 162.745 \\
\hline
\end{tabular}

Keterangan :

df : derajat kebebasan

S : variansi

$$
\begin{aligned}
\mathrm{X}_{\text {hitung }} & =\text { in } 10 \mathrm{~B}-(\mathrm{ni}-1) \log \mathrm{S1}^{2} \\
& =2.3026(162.939-162.745) \\
& =2.3026 \times 0.194 \\
& =0.447 \\
\mathrm{X}_{\text {tabel }} & =\mathrm{X}^{2}(0.95)(3) \\
& =7.81
\end{aligned}
$$

Hasil perhitungan homogenitas populasi pengetahuan lingkungan menunjukkan bahwa harga $\mathrm{X}^{2}$ hitung adalah 0.447 lebih kecil dari $\mathrm{X}^{2}$ tabel 7.81 sehingga Ho diterima pada taraf nyata 0.05. Kesimpulannya populasi memiliki variansi yang homogen.

Sementara itu pengujian persyaratan analisis pada data moral lingkungan ditunjukkan oleh tabel berikut ini:
Tabel 5. Hasil Uji Homogenitas Variansi Moral Lingkungan

\begin{tabular}{|l|l|l|l|l|l|}
\hline Kelompok & Dk & Si2 & dk $x$ Si2 & LogSi2 & dk. LogSi2 \\
\hline Industri & 37 & 44.159 & 1638.883 & 1.645 & 60.865 \\
\hline Kota & 34 & 19. & 644.946 & 1.278 & 43.452 \\
\hline Pantai & 44 & 32.026 & 1409.149 & 1.585 & 69.740 \\
\hline Sawah & 39 & 56.563 & 2205.973 & 1.752 & 66.347 \\
\hline & 154 & & 5893.951 & & 242.405 \\
\hline
\end{tabular}

$$
\begin{aligned}
\mathrm{X}^{2}{ }_{\text {hitung }} & =\text { in } 10 \mathrm{~B}-(\mathrm{ni}-1) \log \mathrm{S}^{2} \\
& =2.3026(243.763-242.4045) \\
& =2.3026 \times 1.358 \\
& =3.128 \\
\mathrm{X}_{\text {tabel }} & =\mathrm{X}^{2}(0.95)(3) \\
& =7.81
\end{aligned}
$$

Dari hasil perhitungan menunjukkan harga $\mathrm{X}^{2}$ hitung sebesar 3.128 lebih kecil dari $\mathrm{X}^{2}$ tabel sebesar 7.81 sehingga Ho juga diterima pada taraf nyata 0.05 . Kesimpulannya populasi memiliki variansi yang homogen.

\section{Pengujian Hipotesis}

Pengujian hipotesis penelitian bertujuan untuk mengetahui apakah hipotesis yang diajukan ditolak atau diterima pada taraf kepercayaan tertentu. Dalam penelitian ini terdapat 2 hipotesis yang akan diuji.

Pengujian hipotesis penelitian menggunakan Analisis Kovarian (ANAKOVA) untuk mengetahui apakah model berwawasan lingkungan yang disusun dapat meningkatkan pengetahuan dan moral lingkungan siswa. Selain itu apakah modul tersebut dapat digunakan pada masing-masing sekolah dengan latar belakang lokasi berbeda.

\section{Uji Hipotesis Terhadap Pengetahuan Ling-kungan}

Kriteria Pengujian

Ho : diterima bila $\mathrm{t}_{\text {hitung }}<\mathrm{t}_{\text {tabel }}$

$\mathrm{Hi} \quad$ : ditolak bila $\mathrm{t}_{\text {hitung }}>\mathrm{t}_{\text {tabel }}$

Perhitungan : 
Tabel 6. Rangkuman Hasil Perhitungan Anakova Pengetahuan Lingkungan.

\begin{tabular}{|c|c|c|c|c|c|c|c|c|c|}
\hline $\begin{array}{l}\text { Sumber } \\
\text { Varansi }\end{array}$ & $\mathrm{dk}$ & JK & Produk & Silang & Dikoreks & & & Fhit & $\begin{array}{l}\mathrm{F} \\
\text { tab }\end{array}$ \\
\hline & & Y & $X Y$ & $X$ & y & dk & KT & & \\
\hline Ant. Kel. & 3 & 23,16 & & 323.39 & & & & & \\
\hline Dalam Kel. & 154 & 15289.16 & 14504.41 & 5837.78 & 14504.41 & 153 & 94:80 & 0.31 & 2.68 \\
\hline Jumlah/Tot. & 157 & 15330.59 & 14622.13 & 6161.17 & 14622.13 & 156 & & & \\
\hline AntKel. & & & & & 11.83 & 3 & 3,94 & & \\
\hline
\end{tabular}

Dari tabel ANAKOVA di atas diperoleh nilai statistik $F=3,84 / 1,93=1,989$ yang lebih kecil dari $F$ tabel $(0.005)(\mathrm{v} 1: 3)(\mathrm{v} 2: 156)=2.68$. Hal ini berarti bahwa Ho: diterima. Dengan demikian modul berwawasan lingkungan yang telah disusun dapat digunakan untuk meningkatkan pengetahuan siswa SD tentang lingkungan dan dapat digunakan di SD dengan latar belakang berbeda (industri, kota, pantai dan persawahan).

\section{Uji Hipotesis Terhadap Moral Lingkungan}

\section{Kriteria Pengujian}

Ho : diterima bila $\mathrm{t}_{\text {hitung }}<\mathrm{t}_{\text {tabel }}$

$\mathrm{Hi} \quad$ : ditolak bila $\mathrm{t}_{\text {hitung }}>\mathrm{t}_{\text {tabel }}$

Perhitungan :

Tabel 7. Rangkuman Hasil Perhitungan Anakova Moral Lingkungan

\begin{tabular}{|c|c|c|c|c|c|c|c|c|c|}
\hline \multirow[t]{2}{*}{$\begin{array}{l}\text { Sumber } \\
\text { Varansi }\end{array}$} & \multirow[t]{2}{*}{$\mathrm{dk}$} & \multirow[t]{2}{*}{ JK } & \multirow{2}{*}{\begin{tabular}{|l|} 
Produk \\
$X Y$ \\
\end{tabular}} & \multirow{2}{*}{\begin{tabular}{|l} 
Silang \\
$X$ \\
\end{tabular}} & \multicolumn{3}{|c|}{ Dikoreksi } & \multirow[t]{2}{*}{ F hit } & \multirow[t]{2}{*}{$\begin{array}{l}\mathrm{F} \\
\mathrm{tab}\end{array}$} \\
\hline & & & & & $y$ & $\mathrm{dk}$ & KT & & \\
\hline Ant. Kel. & 3 & 23,16 & & 323.39 & & & & \multirow{3}{*}{0.31} & \multirow{3}{*}{2.68} \\
\hline Dalam Kel. & 154 & 15289.16 & 14504.41 & 5837.78 & 14504.41 & 153 & 94.80 & & \\
\hline Jumlah/Tot. & 157 & 15340.59 & 14622.13 & 6161.17 & 14622.13 & 156 & & & \\
\hline Ant Kel. & & & & & 11.83 & 3 & 3,94 & & \\
\hline
\end{tabular}

Dari tabel ANAKOVA di atas untuk menguji apakah modul berwawasan lingkungan dapat digunakan untuk siswa SD dengan latar belakang berbeda diperoleh nilai statistik $\mathrm{F}=3.94 / 94.80=0.31$ yang lebih kecil dari $\mathrm{F}_{\text {tabel (0.005)(v1:3)(v2:156) }}=2.68$. Hal ini berarti bahwa Ho: diterima. Dengan demikian modul berwawasan lingkungan yang telah disusun dapat digunakan untuk SD dengan latar belakang berbeda (industri, kota, pantai dan persawahan). Penggunaan modul pada masing-masing lokasi SD tersebut dapat juga untuk meningkatkan moral lingkungan siswa.

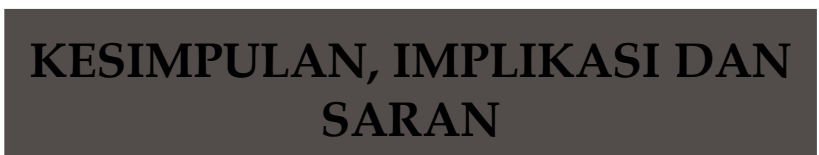

\section{Kesimpulan}

Hasil perhitungan menunjukkan bahwa kedua hipotesis yang diujikan dalam penelitian (Ho) diterima dan (H1) ditolak. Hal ini berarti bahwa (1) secara keseluruhan rata-rata pengetahuan siswa tentang iingkungan dapat ditingkatkan dengan menggunakan sistem pengajaran melalui modul berwawasan lingkungan, (2) rata-rata moral siswa tentang lingkungan dapat ditingkatkan melalui sistem pengajaran dengan menggunakan modul berwawasan lingkungan, (3) pengetahuan dan moral siswa tentang lingkungan ternyata secara bersamasama dapat ditingkatkan dengan menggunakan sistem pengajaran modul yang berwawasan lingkungan, (4) selain dapat meningkatkan rata-rata pengetahuan dan moral siswa tentang lingkungan, sistem pengajaran dengan menggunakan modul berwawasan lingkungan tersebut ternyata dapat digunakan untuk pengajaran di SD dengan latar belakang lokasi sekolah yang berbeda.

Kesimpulan hasil penelitian tersebut di atas secara lebih rinci adalah sebagai berikut:

Pertama secara keseluruhan moral siswa tentang lingkungan hidup pada masing-masing SD dapat ditingkatkan. Pengujian hipotesis terhadap data moral siswa tentang lingkungan hidup melalui uji Anacova diperoleh harga $\mathrm{F}_{\text {hitung }}$ sebesar, 0, 31 yang lebih rendah dari harga $\mathrm{F}_{\text {tabel }}(0,05)(\mathrm{v} 1: 3)(\mathrm{v} 2: 156)$ sebesar 2. 68. Karena $\mathrm{F}_{\text {hitung }}$ lebih kecil dari $\mathrm{F}_{\text {tabel }}$ maka Ho diterima. Hal ini berarti sistem pengajaran dengan menggunakan modul tersebut dapat digunakan untuk meningkatkan moral siswa SD di daerah industri, pantai, kota dan persawahan.

Kedua moral siswa tentang lingkungan secara keseluruhan meningkat dengan menggunakan sistem pengajaran modul berwawasan lingkungan. Dari pengujian hipotesis terhadap data pengetahuan siswa tentang lingkungan menggunakan uji Anacova diperoleh harga $\mathrm{F}_{\text {hitung }}$ sebesar 1,989 yang lebih rendah dari harga $\mathrm{F}_{\text {tabel }}(0,05)(\mathrm{v} 1: 3)(\mathrm{v} 2: 156)$ sebesar 2. 68. Karena $\mathrm{F}_{\text {hitung }}$ lebih kecil dari $\mathrm{F}_{\text {tabel' }}$ maka Ho diterima. Hal ini berarti bahwa pengetahuan siswa tentang lingkungan hidup di daerah industri, kota, pantai dan persawahan dapat ditingkatkan dengan menggunakan sistem pengajaran modul yang berwawasan lingkungan. 


\section{Implikasi Penelitian}

Upaya-upaya lain yang dapat dilakukan untuk meningkatkan pengetahuan dan moral siswa tentang lingkungan adalah:

Pertama siswa sendiri harus berusaha lebih giat untuk belajar di sekolah dan di rumah, aktif mengerjakan tugas-tugas yang diberikan oleh guru, waktu luang dapat digunakan untuk menambah wawasan melalui membaca modul ini secara berulang dan memahami kalimat-kalimat yang sulit dimengerti atau dapat juga digunakan untuk melihat acara televisi yang ada hubungannya dengan lingkungan.

Kedua orang tua siswa sangat berperan dan membantu dalam menciptakan suasana belajar yang mendukung misalnya tersedianya ruang untuk belajar dengan suasana yang tenang. Anak sebaiknya diberi kesempatan belajar tanpa harus diganggu dengan tugas-tugas lainnya. Waktu belajar harus diatur agar anak terbiasa dengan hidup disiplin.

Ketiga motivasi dan semangat belajar harus terus dilakukan oleh orang tua kepada anaknya. Hal ini disebabkan karena pada usia sekolah kepribadian siswa cenderung bersifat fluktuatif. Anak belum memiliki kemapaman dalam berpikir oleh sebab itu dorongan dan motivasi orang tua sangat diperlukan untuk menjaga agar kepribadian anak tetap stabil ke arah yang lebih baik.

Keempat sejak dini orang tua harus memberikan contoh-contoh tentang apa yang boleh dan tidak boleh dilakukan terhadap alam. Orang tua juga dapat menerangkan kemungkinan-kemungkinan bencana apa yang akan terjadi jika manusia merusk lingkungan atau sebaliknya keuntungan-keuntungan apa yang akan didapat manusia jika memelihara kelestarian lingkungan. Penerapan cara ini akan lebih baik bila orang tua menghubungkan masalah lingkungan dengan adat istiadat dan masalah dosa dan pahala dalam agama.

Kelima guru harus mempersiapkan diri dengan baik pada saat akan mengajar. Persiapan yang dibutuhkan bukan hanya sebatas materi dan media saja, tetapi juga kesiapan menghubungkan materi dengan realitas sosial yang terjadi di masyarakat. Dengan demikian maka siswa akan merasa senang dalam belajar karena materi yang dibahas memiliki hubungan dan akan bermanfaat dalam kehidupan sehari-hari.

Keenam masyarakat harus diberi kesadaran agar mendukung kegiatan beajar siswa di sekolah maupun di luar sekolah. Usaha-usaha yang dapat dilakukan misalnya memberikan contoh yang sesuai dengan adat-istiadat dan norma-norma sosial yang berlaku, bertingkah laku sesuai ajaran agama. Selain itu upaya lain yang dapat dilakukan adalah menjaga ketentraman lingkungan yang bebas dari suasana bising dan polusi sehingga anak dapat belajar dengan baik.

\section{Saran-saran}

Berdasarkan kesimpulan, implikasi dan hasil penelitian, maka agar siswa memiiliki kecenderungan untuk belajar lebih giat sehingga dapat meningkatkan hasil belajar pengetahuan siswa tentang lingkungan disampaikan saran-saran sebagai berkut:

Pertama perlu dilakukan upaya yang terus menerus untuk meningkatkan motivasi siswa dalam belajar. Hal ini disebabkan karena motivasi merupakan faktor pendorong yang sangat penting untuk menggerakkan siswa mencapai hasil belajar yang baik. Bentuk-bentuk pujian dan penghargaan kepada siswa yang berhasil dalam kegiatan tertentu merupakan salah satu cara yang dapat dilakukan.

Kedua guru perlu terus meningkatkan ketrampilannya melalui berbagai kegiatan yang akan membantunya dalam menjelaskan bahan palajaran kepada siswa melalui kegiatan membaca literatur baru, mengikuti seminar, penataran atau diskusi dengan sesama guru lainnya.

Katiga mengingat sebagian besar orang tua siswa terutama di daerah industri, pantai dan sawah memiliki tingkat pendidikan yang rendah maka disarankan agar pemuka masyarakat, aparat terkait dapat membina dan menyadarkan orang tua tentang pentingnya pendidikan bagi anak. Bila perlu mereka dapat menggantikan peran orang tua yang dapat memberikan motivasi belajar kepada siswa

Keempat perlu dilakukan penelitian verifikasi lebih lanjut dengan menggunakan lokasi yang berbeda dan jenjang pendidikan yang berbeda pula, misalnya penelitian yang menggunakan subjek siswa SLTP.

Kelima untuk menggunakan hasil penelitian ini dalam kegiatan secara masal. Maka diperlukan pertimbangan terhadap berbagai faktor seperti kondisi siswa, lingkungan sekolah sehingga dalam pelaksanaannya tidak memperoleh hasil yang jauh berbeda dengan hasil penelitian ini.

\section{DAFTAR PUSTAKA}

Ahmad, N. (2002). Etika dan moral menurut AlGhazali. Dikdatika Islamika. Vol. 3 Nomor 8.

Perspektif Ilmu Pendidikan - Vol. 13 Th. VII April 2006 
Arikunto, S. (1980). Manajemen pengajaran secara manusiawi. Jakarta: Rineka Cipta.

Barmadib, S. I. (1987). Pengantar ilmu pendidikan sistematis. Yogjakarta: FIP IKIP Yogyakarta.

Budiningsih, A. (2001). Analisis karakteristik siswa kaitannya dengan tahap-tahap perkembangan penalaran moral. Jurnal Teknodik. No. 9.

Darsono, V. (1995). Pengantar ilmu lingkungan. Yogjakarta: Atma Jaya.

Davies, I. K. (1991). Pengelolaan belajar. Jakarta: Rajawali Pers.

Djanegara, R. A. S. (1986). Pengantar metodologi penelitian pendidikan. Jakarta: Proyek Pengembangan Perguruan Tinggi IKIP Jakarta.

Durkheim, E. (1990). Pendidikan moral suatu studi teori dan aplikasi sosiologi pendidikan. (L. Ginting, Penterjemah). Jakarta: Erlangga.

Engkoswara. (1988). Dasar-dasar metodologi pengajaran. Jakarta: Bina Aksara.

Grounlund, N. E. (1985). Measurement and evaluation in teaching. New York: Macmillan Publishing Company.

Haricahyono, C. (1995). Dimensi-dimensi pendidikan moral. Semarang: IKIP Semarang Press.

Hurlock, E. B. (1994). Psikologi perkembangan suatu pendekatan sepanjang rentang kehidupan. (Istiwidayanti \& Soedjarwo, Penterjemah). Jakarta: Erlangga.

Krathewahl, D. R., Bloom, B. S., \& Masia, B. B. (1964). Taxonomy of educational objectives the classification of educational goals. London: Longmas.
Lee, J. A. (1985). The environment, public health and human ecology condition for economic development. Baltimore: The John Hopkins University Press.

Nasution, (1992). Berbagai pendekatan dalam belajar mengajar. Jakarta: Bumi Aksara.

Nata, A. (2001). Pendidikan agama dan moral dalam perspektif global. Jurnal Mimbar Agama dan Budaya. Vol. XVIII Nomor 3.

Soerjani, M. R. A., \& Munir, R. (1987). Lingkungan sumber daya alam dan kependudukan dalam pembangunan. Jakarta: UI Press.

Sudjana, N. (1990). Penilaian hasil proses belajar mengajar. Bandung: Remadja Rosdakarya.

Suriasumantri, J. S. (1984). Filsafat ilmu sebuah pengantar populer. Jakarta: Sinar Harapan.

Suryosubroto. (1984). Sistem pengajaran dengan modul. Jakarta: Bina Aksara. (1988). Dasar-dasar psikologi untuk pendidikan di sekolah. Jakarta: Prima Karya.

Tanlain, W., dkk. (1989). Dasar-dasar ilmu pendidikan. Jakarta: Gramedia.

Tirtarahardja, U., \& Sula, L. (2000). Pengantar pendidikan. Jakarta: Rineka Cipta.

\section{KETERANGAN PENULIS}

Drs. Bambang Gonggo Mucitro, M.Pd, dilahirkan di Bandung pada tahun1867. Saat ini menjadi staf pengajar di PGSD, serta menjadi dosen pengajar untuk mata kuliah MKU dan MKDK di Universitas Negeri Jakarta. Hasil karyanya yang berupa buku yaitu Ensiklopedi Sains Anak yang diterbitkan tahun 2006. 